NOAH BAR GOSEN

Higher Studies Israel

\title{
DIFFERENT ROLE PERCEPTIONS AND STUDENT-TEACHER RELATIONSHIP CHARACTERISTICS, AMONG HIGH SCHOOL HOMEROOM EDUCATORS AND SUBJECT TEACHERS' - RESULTS FROM A QUALITATIVE RESEARCH
}

\begin{abstract}
Gosen Noah Bar, Different Rola Perceptions and Student-Teacher Relationship Characteristics, Among High School Homeroom Educators and Subject Teachers' - Results From a Qualitative Research [Różne percepcje ról i cech relacji uczeń-nauczyciel u wychowawców klas oraz nauczycieli przedmiotu - wyniki badań jakościowych]. Studia Edukacyjne nr 36, 2015, Poznań 2015, pp. 381-400. Adam Mickiewicz University Press. ISBN 978-83-232-2958-2. ISSN 1233-6688. DOI: 10.14746/ se.2015.36.22

Teaching staff in Israel is expected to fulfill the role of civil and moral educators alongside their instructional roles. In order to achieve that goal, the Israeli education system has defined two distinct entities: the first is the unique position of the "mechanech kita", or a homeroom educator, whose role is to address all aspects of the students' lives. The second role is the subject teacher, who teaches a specific subject in various classes. Semi-constructed interviews of 14 high school teaching staff helped to shed light on the perceptions and practices concerning role definition and the teacherstudent relationship. The results show that homeroom educators emphasize a holistic view and perceive responsibility for the "whole student". Both instructors valued a strong and consistent relationship with their students, but homeroom educators invested more time and employed more varied strategies to achieve it. Subject teachers emphasized scholastic aspects and practices. The results show that different role definitions lead to different role perceptions and student-teacher relationship characteristics. Further research concerning the implications of such differences on educational and inclusive processes within the school system. Implications concerning teachers' professional training course should be considered as well.
\end{abstract}

Key words: homeroom educators, subject teachers, role definition, role perception, student-teacher relationship, inclusive practice

Education is considered to be one of the most powerful social agents in the modern state. It has the power to promote social cohesion through a sys- 
tem based on equality, justice and free education for all ${ }^{1}$. Two centuries after the industrial revolution, schools serve as institutions where socializations processes take place ${ }^{2}$ while teachers fulfill the role of promoting moral and social development as well as providing education and knowledge to their students. Both objectives are pursued within the relevant cultural and social contexts in which the school system operates ${ }^{3}$. Through the years each objective has developed rationale, practices and evaluation methods that are deemed essential to its achievement. These methods can be parallel, intersecting or complimenting in different instruction contexts as well as in different schools and education systems. Therefore, when general educational targets are being defined, the differentiation existing within the teachers' role definition must be taken into account.

\section{Teaching and socialization aspects within the teachers' role definition}

Supporting socialization processes and teaching go hand in hand within the school's framework and instruction practices. They represent two aspects of the fine art of education. As all educators are teachers and all teachers are expected to be educators, these aspects can be seen as unique and complementing at the same time.

Instruction, or teaching, focuses on transmitting knowledge and skills aiming at educational excellence. Supporting socialization processes aspect concentrates on providing professional mentoring to life, aiming at personal and societal excellence ${ }^{4}$. The teaching task focuses on the employment of various methods aimed to encourage learning processes which are characterized by the accumulation of knowledge ${ }^{5}$. It is a deliberate process aimed at introducing the student to the world of achievements ${ }^{6}$. Supporting socialization processes aspect focuses on emotional, social and ethical aspects as part of the student's personal growth and maturation process, as an individ-

1 G. Bernahu, Inclusive Education in Sweden: Responses, Challenges, and Prospects, 2011, p. $128-148$.

2 S. Bowels, Understanding Education and the Reproduction of the social division of Labor New York 1977,

${ }^{3}$ T. Adar, An Introduction to Education and Teaching, Tel Aviv 1974, p. 9-23.

${ }^{4}$ N. Aloni, Preface: The Philosophy as the Love of Wisdom and the Yearning for Comprehensive Understanding in the Art of Life, Tel Aviv 2005.

${ }^{5}$ R.S. Peters, What is an Educational Process?, London 1966.

${ }^{6}$ M. Oakeshott, Learning and Teaching, London 1966. 
ual as well as a part of a social group ${ }^{7}$. In this process, based on Korczak's perception, the adult - i.e. the educator - serves as an enabler for the child's growth and prosperity ${ }^{8}$. It is a deliberate process aimed at encouraging students to fulfill their personal potential and ethical growth, and become involved members of the community, as well as participating and contributing citizens ${ }^{9}$.

The teacher as an instructor will consternate on the acquisition of knowledge, as well as enhancing students' learning abilities ${ }^{10}$. The practices he or she will use will be those that promote learning processes such us literacy competencies - reading, writing, and understanding, as well as behavioral conduct which enables teaching and learning within the classroom. The teacher as an educator will use practices aimed at promoting personal nurturing relationship with the students as individuals, as well as part of a social group. The teacher will consider the student as a human being, deserving of support and respect; a whole person who needs special attention, assistance and understanding from his teacher ${ }^{11}$.

Evaluation methods of the teaching aspects include tests at class level, national level (Meitzav ${ }^{12}$ ) and international level (PISA ${ }^{13}$,TIMSS14). High

7 S. Zidkiyahu et al., Classroom Management, Mofet 200.

8 S. Adan, Henryk Goldszmit - Janusz Korczak - the Man, the Educator, the Author, Jerusalem 2000.

9 S. Zidkiyahu, et. al., Text-Books and Text People' what is the Role of the Mechanech in the Jewish Secular High School in Israel, and what is the Place of the Jewish Texts within that Role? Diss., 2011.

${ }_{10}$ M. Oakeshott et.al.

${ }^{11}$ J. Korczak, The Child Religion, Trans. D. Sadan and Z. Arad, Lochamey Hgetaot, 1978.

12 A Hebrew acronym for Measures of School Effectiveness and Growth. The MEITZAV standardized achievement tests are intended to examine to what extent elementary and junior high school students meet requirements based on the curriculum in four core subjects: science and technology, English, mother tongue (Hebrew/Arabic), and mathematics, at two grade levels (5th and 8th). Tests are administered in mother tongue competency in the second grade as well (Razer, Mittelberg, Motola and Bar Gosen, 2015. P. 17). When the tests are external, i.e. checked and evaluated by external personnel from the Ministry of Education, a survey checking school climate is added to the tests.

13 The PISA is an international study conducted by the Organization for Economic Cooperation and Development (OECD), which Israel joined in 2010. The study was launched in 2000, and takes place once every three years. Its goal is to examine to what extent 15year-old students are 'ready for adult life', that is, they have acquired general thinking and comprehension skills and understanding in a way that allows them to cope well and effectively with their environment. The study tests literacy levels in three disciplines: reading, mathematics, and science. Each study cycle focuses on one of these three areas (though the two others are also measured). In the 2009 PISA study, the emphasis was on reading literacy. (Razer, Mittelberg, Motola and Bar Gosen, 2015. P. 17).

14 TIMSS: an assessment in the framework of the IEA Trends in International Mathematics and Science Study (TIMSS). TIMSS assessed student achievement in mathematics and science 
schools are evaluated by their rates of students who matriculate as well as their average matriculation scores ${ }^{15}$. Evaluation Methods concerning the educating aspects are less defined and formulated: 16 Dropout rate can be a measure for the school inclusive abilities; ${ }^{17}$ School climate survey, which is a part of the Meitzav, tests parameters such as teacher-student relationships, school violence, and sense of security, and thus can be considered as an evaluation tool for educational objectives. Additionally, in recent years, the Ministry of Education annually ranks high schools according to parameters such as evaluation and tests' integrity, social achievements, and civil excellence. The ranking list is then published in the media ${ }^{18}$.

Teachers are professionals who are expected to teach based on their acquired knowledge, and pedagogic and methodological skills ${ }^{19}$. They are expected to be educators who implement valuable social and moral aspects as part of their ongoing relationship with their students ${ }^{20}$. Their training emphasizes pedagogic and methodological skills as well as broader educational issues concerning child development, learning processes, and promoting social interaction within the classroom. However, in comparison with the aspect of teaching, the socialization aspect, although embedded in the role of the homeroom educator, is less defined and taught. It has been questioned whether it can be taught at all ${ }^{21}$.

Although the socialization and instructional aspects were described here through the emphasis on their differentiated variables, in reality they are complementary and interrelated. Responsibility and responsiveness from the teacher, as manifested in the socialization aspect, is an important tool for achieving instructional objects as well enhancing students' personal growth and learning abilities 22 .

at the fourth and eighth grades, as well as trends over a 16-year period. The previous cycles of TIMSS were conducted in 1995, 1999, 2003, 2007, 2011 (http://www.iea.nl/timss_2011.html ).

${ }^{15} \mathrm{M}$. Razer et al., Israeli high school teachers' perceptions and attitudes towards a pedagogy of inclusion, 2015, DOI: 10.1080/13603116.2015.1019373

16 S. Sherman, Responsiveness in Teaching: Responsibility in Its Most Particular sense, 2004, p. 115-124.

17 M. Razer et al., Inclusion and Achievement in Education: Contradictory or Complementary Goals? Oranim, 2013, p. 11-28.

18 Walla! News 'where do most moral and ethical high school students in Israel study?' [Access: 11.8.15].

${ }^{19}$ Council for Higher Education. the Council Resolution Concerning 'Guidelines for Teachers Training Program in Academic Institutions in Israel - Ariav Committee Report. Israel 2006.

20 Council for Higher Education et al.

${ }^{21} \mathrm{~J}$. Korczak, The Child Religion.

$22 \mathrm{~S}$. Sherman, et al. 


\section{Two distinct roles within the Israeli education system: the homeroom educator and the subject teacher}

The Zionist movement in Israel, at the beginning of the $20^{\text {th }}$ century, wished to abandon the conventional religious educational methods. It sought to adapt a modern way of education as performed in the European states. The renewed school system served under the dominance of the National Institutes (the governing institutions prior to the establishment of the Jewish state) as a tool to consolidate the national consciousness of the Israeli citizens of the future state ${ }^{23}$. School teachers were expected to fulfill the role of civil and moral educators alongside instructional roles. Students were divided according to age, into homeroom classes- called Kita - a social unit which stays constant during the school year, and where most subjects were being taught. Students could be part of the same Kita during their entire school years. Each Kita has a homeroom educator ${ }^{24}$, who remains constant throughout the year, and sometimes longer than a year. The homeroom educator also serves as a subject teacher within the school, at his/her class and other classes. The homeroom educator complex role definition is unique to the Israeli education system ${ }^{25}$.

Thus, the Israeli education system has defined two different professional roles among school teachers ${ }^{26}$ : The role of the homeroom educator - the 'Mehcanech', originated from the Hebrew word 'chinuch' meaning education - who focuses on the educational - i.e the socialization processes' aspects, and the subject teacher - 'Moreh' from the Hebrew word 'Hora'ah' means instruction or teaching - who focuses on the instructional/ teaching aspects of his/her specific subject. In Israel, these terms represent two different role definitions that operate side by side in the Israeli school system. BakshiBrosh ${ }^{27}$ claims that the role differentiation is a conscious organizational phenomenon which manifested also in a different salary structure and differentiated work procedures between homeroom educators and subject teachers.

A comprehensive literature review concerning the origin and differences between homeroom educators and subject teachers was executed by several researchers ${ }^{28}$. A review of the main points is included here.

${ }^{23}$ T. Lam, Educational Ideologies and Teaching Methods, Tel Aviv University 1999.

${ }^{24}$ D. Gordon, W.I. Ackerman, The Mechanech: Role Function and Myth in Israeli secondary Schools, 1984, p. 105-115.

${ }^{25}$ S. Zidkiyahu, et al.

${ }^{26}$ Ministry of Education, et al.

27 I. Bakshi-Brosh, The Significance of the Roles of Homeroom Educators and Subject Teachers in the Israeli Education System, Negev 2005.

${ }^{28}$ I. Bakshi-Brosh, et al. A. Sela, et al. M. Razer, 2015 et al. 
The subject teacher's role description as defined in The Ministry of Education's formal website ${ }^{29}$ indicates that the subject teacher teaches the professional subjects in different classes, according to her/his teaching license and based on the work plan set by the school principal. The teacher is in charge of teaching the subject as well as teaching the students proper learning procedures and work habits. Achievements are measured quantitatively in different knowledge tests at school, and on national and international level. According to this role definition, subject teachers should concentrate on teaching specific knowledge, as well as specific learning strategies that are compatible to the subject domains. Eventually, subject teachers evaluate how well the students internalized that knowledge. It can be assumed, according to this role definition, that subject teachers will be more inclined to use measurable learning processes ${ }^{30}$ and objectives. Their perception of the student will be limited to the subject context. Their sense of responsibility concerning the student will be limited to the scope of their subject. Their relationship with their students will be related to subject context and instructional matters rather than to personal and social concerns.

The homeroom educator's role definition is much broader ${ }^{31}$. Homeroom educators are responsible for addressing all educational and social aspects relevant to their students, as well as the social cohesion of the entire class, and providing for needs which are not entirely learning-related (Razer, et. al. 2015), at the student level and at the class unit level ${ }^{32}$. The homeroom educator is also responsible for maintaining an ongoing, learning-supportive relationship with the students' parents ${ }^{33}$. The homeroom educator role takes the responsibility over the affective aspects of the learning process rather than the actual instruction practices ${ }^{34}$, in a way that can resemble a supportive parenting style. Such similarity can influence student motivation to achieve scholastic and social achievements ${ }^{35}$.

\section{Research questions}

The research question investigates the different role perceptions and student teacher relationship characteristics among high school homeroom

${ }^{29}$ Ministry of Education, et al.

${ }^{30}$ Razer M., et al.

${ }^{31}$ Ministry of Education, et al.

32 Y. Tadmor, Homeroom Teachers as Key Figures in Education, Tel Aviv 1999, p. 200-217.

${ }^{33}$ Ministry of Education, et al.

$34 \mathrm{~S}$. Sherman, et.al

${ }^{35}$ K.P. Wentzel, Are Affective Teachers Are Like Good Parents? Teaching Styles and Student Achievements in Early Adolescence, 2002, p. 287-301. 
educators and subject teachers. Based on the professional literature review as well as the formal role descriptions created the Ministry of Education, it can be assumed that differences will be found between these professionals as related to those aspects of their work. Since the homeroom educator's role focuses on students' personal learning processes as well as students' moral, behavioral and social aspects and social inclusion processes that refer to the class as a social unit, it can be assumed that $\mathrm{s} / \mathrm{he}$ will be more inclined to conduct various interactions with the students and will hold a more holistic perception of them, in comparison with subject teachers. Homeroom educators' sense of responsibility concerning their students will far surpass the scope of their subject of instruction in comparison with subject teachers. Homeroom educators' relationship with their students will be consistent and personal and will relate to aspects other than solely scholastic matters.

\section{Research population}

Twelve semi-open interviews were held with six homeroom educators $(2 \mathrm{~m}, 4 \mathrm{f})$ and six subject teachers (6f). (Age disparity homeroom educators 3855. Age disparity subject teachers 27-64 yrs. Seniority disparity homeroom educators 13-26 yrs. Seniority disparity subject teachers 3-30 yrs). Complementary interviews were held with school counselor and school vice principal (2f, Age disparity 44-50 yrs.).

All of the interviewed teachers work in a rural comprehensive regional high school in the Jewish sector, spanning four years of learning $\left(9^{\text {th }}-12^{\text {th }}\right.$ grades). School population includes approximately 800 students and 100 teachers. Approximately $50 \%$ of the students come from rural and urban settlement surrounding the region. Teachers' population characteristics are very similar to students' population ${ }^{36}$.

School population SES is average. External measures such as matriculation certificate rates, matriculation tests' grades $^{37}$, and military drafting rates $^{38}$ rank the school above average in comparison with other Israeli high schools within the Jewish sector ${ }^{39}$. The school is defined as a regular school and it includes three classes in each grade level for students with different

36 School site [access: Jan. 2015]

37 Ibidem.

38 K. David, http://www.mynet.co.il/articles/0,7340,L-3999693,00.html [Access: August 2015]. (Hebrew)

39 School site [Access: January 2015]. 
levels of learning disabilities. All students are aimed to achieve a partial or full matriculation degree.

All homeroom educators teach as subject teachers in different classes. The homeroom educator meets his class every morning for 15 minutes. At this session $\mathrm{s} /$ he checks attendance, review behavioral reports from the day before, pass information or discuss current events. In addition, s/he holds two homeroom hours in his/her class as part of a planned educational program. In these lessons ethical and social values and events are being discussed as well as current events. The homeroom educator accompanies his/her students to all social and extra-curricular activities taking place as part of the school year, including field trips. Subject teachers teach their classes according to hours assigned to that subject (2-4 lessons per week). Subject teachers who teach in stratified subjects (Math or English for example) or a specific subject like Physics or Electronics, which is not a core subject, will meet a selected group of students every lesson, but never the whole class. As a whole, a homeroom educator is responsible for 20-35 students in his homeroom class. A subject teacher meets several classes, thus his/her instructional responsibility scope can be over a hundred students.

\section{Research Methods}

Qualitative interviews ${ }^{40}$ using semi - structured interviews with open questions, were held with every teacher individually. The emphasis on qualitative methodology was chosen in order to receive a naturalistic and descriptive data which, through an inductive analytic process, can bring out the meaning the teachers give to their role definition, behaviors and attitudes ${ }^{41}$.

The interviews were based on questions regarding specific foci that are part of the teachers' role scope. Role definition - i.e. homeroom educator or subject teacher, defined goals, values and successes within that role, evaluation of professional training prior and during their teaching experience, relationship with students, peers and students' parents, attitudes toward disciplinary issues, and inclusive practices, and their perception of the student and their responsibility toward him.

All interviews took place in the second trimester of the school year. Most interviews took place outside school premises. Each interview length was

${ }^{40}$ R.K. Yin, Qualitative Research From Start to Finish, NY 2011.

${ }^{41}$ R.C. Bogdan, S.K. Biklen, Qualitative Research for Education - an Introduction To Theories and Methods, U.S.A. 2007. 
approximately one hour. All teachers interviewed expressed gratitude for the opportunity to reflect on their profession, use insight, and be heard. All teachers interviewed expressed satisfaction of their daily work as teachers. After obtaining interviewees' consent, all interviews were documented.

Due to existing personal and professional relationships with teaching staff, special precautious had to be taken in order to remain neutral and objective during the interviews. As a whole, the interviewees were very open and candid. The interviewees spoke their mind and reflected on their professional behaviors, values and attitudes. The position of an interested listener was kept without imposing or directing the interviewed teachers ${ }^{42}$.

After coding the answers, the perceived data was categorized according to main themes; teachers' student perception, student teacher relationship and role practices and objectives. The qualitative analyses revealed three prominent themes: The first theme relates to the teachers' perception of the students and the definition of teacher's responsibility toward the students. The second theme relates to student-teacher relationship, their importance, frequencies and means of communication. The third theme relates to underlining characteristics of role definitions and practices on the continuum between teaching or instructional aspects and educational aspects.

\section{Analysis}

Analysis will be presented in three sections. In the first section each theme will be presented together with answers distribution and prominent relevant quotes. At the second section an in-depth discussion will be presented, in which themes and leading quotations will be analyzed within a theoretical context. Lastly, generalizations and implications will be concluded as practical implications, further research suggestions and a foundation for drafting a quantitative questionnaire which will be the center of the complete research.

\section{First theme: Perception of the students}

High school students come from various SES, family structures, and contexts. They all take part in the long difficult journey to achieve their matriculation degree in various subjects - core subjects and subjects of choice 
-a journey which makes them face various teachers and scholastic demands. They also take part in social activities and experience peer support and competition. They are students, children, sons, and daughters. Therefore, it is important to understand what do teachers, in different roles, 'see' or take into account, from these aspects.

Homeroom educators expressed a more holistic view of their students, and a higher sense of responsibility, in comparison with subject teachers. This perception can be seen in three dimensions:

1. "Every child is a whole world..."

The idea that a student is much more than just a student was expressed specifically by one homeroom educator, but variations of this perception were stated by all homeroom educators: "Every child is a whole world... every day is special and every child is special..." $(Y, 50)$ "We have a broader picture of the student..." (I, 55) "To know the kids in depth and to be there for them...especially if they have difficulties or problems they cannot overcome by themselves... This is the homeroom educator class and he knows the children best..." $(D, 45)$

Subject teachers expressed their lack of knowledge about the students' lives outside the classroom and acknowledged the fact that homeroom educators possess that knowledge: "I consult with the homeroom educator who knows the children much better... the homeroom educator has information that only he knows..." $(Y, 64)$ "The subject teacher's role is narrower. Homeroom educators have a broader view of the student and the learning process...I don't deal with things that happens at [the student's] home or life. It is a big different..." (I, 55)

2." ...for some of my students I take the place of a parent."

The close and nurturing relationship between the homeroom educator and their students can sometime resemble parental relationships. Interviewed homeroom educators reflected on that subject and expressed parental feelings and attitudes toward their students: "I wanted to be close to them. I think it expresses the parental perception I have of my role" $(D, 48)$ "Every year I discover that for some of my students I take the place of a parent. I see it as part of my role..." (M. 38) "In the class that you educate, the children are yours for years... you are highly committed..." (D. 45)

Subject teachers also acknowledged the strong attachment between homeroom educators and their students. Some were very clear about the differences they see between their role as teachers and the parental role. "I am a teacher, and most regular children have enough friends and adults in their lives." ( $L$, 56) "A subject teacher can perform his role more neatly... $(H, 27)$. "A subject teacher role... protects me from involvement, disappointment, frustration and expectations. Everything takes place within the realm of my field of expertise..." (M. 48). 


\section{3. "It is a $24 / 7$ kind of responsibility"}

The role of the homeroom educator encompasses vast responsibilities concerning the student scholastic, behavioral, personal, social and ethical aspects. Homeroom educators expressed their sense of responsibility as a never-ending obligation. They also recognized the wide scope of this responsibility, which covers all school activities as well as external events which affect the students' performance and behavior at school: "It is a 24/7 kind of responsibility..." $(D, 45)$ "A field trip is the homeroom educator. Every problem in the evening is the homeroom educator's problem. I am their address for every problem at school... usually and as the first step it is definitely the homeroom educator..." (I, 55) "A subject teacher concentrates on learning. I do all the other processes... I need to be on duty all the time. It's a daily routine..." $(Y, 50)$ "My availability for them is nearly endless..." $(M, 38)$

Subject teachers defined their responsibility as more limited and confined to the realm of their subject: "The educating role demands the split between teachings and looking after the classroom which takes 24 hours a day...I am not responsible for them like the homeroom educator... I don't feel like an educator because I am not defined as one... I like to invest everything in teaching... as a homeroom teacher I couldn't find the time for it..." (L, 56). "My Experience as a homeroom educator made me give up that role. It took a lot of time, technical activities, high emotional involvement..." $(M, 48)$ "Homeroom educators are responsible for everything that happens to the child beyond the scope of the specific lesson. I am responsible only for the subject and to what happens in the lesson itself" $(M, 33)$.

\section{Second Theme: teacher -student relationship}

School is where students and teachers meet. Most instruction, teaching and learning processes take place within the realm of teacher -student relationships. These relationships can be a key factor to students' success or failure. Therefore, it is imperative to identify how teachers in different roles perceive these relationships.

Homeroom educators and subject teachers both valued the existence and preservation of teacher-student relationships. Homeroom educators invested more time and performed more activities designed to form and preserve these relationship. Three dimensions were identified:

1. "If you want to do it well you must have this relationship" Consistent and supportive relationships between teachers and students are perceived as vital for achieving scholastic and educational targets, and both teachers and students are encouraged to sustain personal and direct communication. All 
the interviewed teachers emphasize the importance in creating and sustaining these relationships. All the interviewed teachers described their communication practices. All interviewees agreed that homeroom educators invested more time and effort in order to sustain ongoing relationships with their students, in comparison with subject teachers. The scope of these relationships varied and included personal, scholastic, social and behavioral aspects.

"Listening comes before everything else. The ability to listen to the students all the time. Personal conversations. I want to get to know the children, to hear them openly and directly." $(D, 45)$ "I don't have transparent students, I don't ignore any of my students... Many conversations, endless conversations. To let [the student] know that it is important to me that he will be in the classroom..." $(H, 55)$

Subject teachers emphasized the importance of sustaining an ongoing relationship with their students. Their relationships with the students and the communication with them was related mainly to the subject they taught in class. "I communicate with most of the students, but I say frankly that due to classes' size I cannot reach all of them... I don't reach the quiet children, the transparent ones...' $(Y, 64)$ "As a subject teacher I don't feel I keep constant relationship with everyone. It takes me almost a year to get to know the new students and to establish relationships..." (I, 55)

2. Different communication methods between teachers and students.

In order to establish, preserve and promote consistent communication among teachers and students, there are various means of communication available. The school formal tool of communication is the Mashov ${ }^{43}$.Other means of communication can be personal conversation, dialogue hour (a lesson dedicated to student-teacher dialogue of choice), SMS, WhatsApp, emails and telephone calls. All teachers are compelled to use the Mashov system and report student conduct and scholastic achievements. Other communication means are open to the teachers' use according to their preference. Homeroom educators and subject teachers use all forms of communication in their attempt to promote teacher-student relationship. Homeroom educators tend to use communication means such as personal conversations and phone calls more often and in a more personal manner than subject teachers.

43 "Mashov" (meaning "feedback" in Hebrew, as well as the acronym of "Immediacy, Transparency, and Supervision") (Mashov website is http://www.mashov.info/ [in Hebrew].) This technology is currently adopted in more than 400 Israeli schools. The system includes two applications: the Mashov staff application enables secure online exchange of pedagogical information and communication between teachers, as well as online interactions with students and their parents; the Mashov family application opens access to student data - for the students and their parents - and offers the possibility for a two-way communication channel with the school staff. (Blau and Hmeiri, 2010, p. 247). 
"I work with them, following the Mashov reports... there are my responses... I sit with them... I try to understand why they misbehave...we have an agreement. If they don't enter a lesson they text me..." $(Y, 50)$ "Morning sessions are the time to see who came and who didn't come... all personal matters are sorted during morning gatherings..." (I, 55) "We have a WhatsApp group for the class where you raise questions, problems, publish homework... I suggested it... Most communication is done through the Mashov..." (H, 27) "I hold personal conversations, if I cannot make it during the lesson. I keep ongoing contact through the Mashov, and dialogue hours. If I want to speak to someone I do it..." (M, 33).

3. "The homeroom educator is perceived as the mediating and connecting factor between the child and the subject teachers"

It is expected that the homeroom educator fulfils the role of the mediator in several contexts: S/he may mediate between the student and the subject teachers when problems or disagreements arise. Sometime s/he will act as the mediator between the subject teacher and the student's parents. In some incidents, the homeroom educator served as a mediator between students and their parents.

The role of mediator, as performed by the homeroom educator, is known and embraced by the subject teachers, and is a part of the school's norms. Though there are times when direct intervention is performed by a subject teacher, it is accompanied by reporting the intervention to the relevant homeroom educator.

"The homeroom educator is perceived as the mediating and connecting factor between the child and the subject teachers" $(Y, 64)$ "A subject teacher can talk with a student after a lesson, but if something repeats itself I get involved in the process..." $(H, 55)$ "some students enter a never ending cycle and I need to step in... Teachers know they turn to me. Things are happening through me..." (Y, 50) "II keep] contact with the homeroom educators in case there is a problem...I will not do anything without consulting the homeroom educator, especially when it comes to more severe reactions or penalties. I will consult with him. It is a mutual decision because he knows them better..." (I, 55) "If I have a problem with a particular student, I turn to his homeroom educator and inform him. Sometimes it is only an update and sometimes we consult how to change the situation..." (M, 33)

\section{Third theme: Teaching aspects and educational aspects in teachers' role perceptions}

Teaching and educating represent two aspects of teachers' role definition. While teaching tends more to the scholastic venues of the teachers' profession, the educational role tends more to the social, personal, ethical and 
behavioral aspects of the teachers' professions. It can be presumed that teachers in different roles will concentrate on different aspects.

Homeroom educators and subject teachers deal with both aspects - , educational and academic aspects, but each emphasizes a different aspect. Subject teachers put more emphasis on scholastic practices and their goals revolve around academic excellence while homeroom educators focus more on personal goals for the students. This comparison is based on three dimensions:

1. "...To give them a chance..."; Declared goals for the students.

All the interviewed teachers expressed their goals concerning their students. Homeroom educators tend to express personal, social and ethical goals as more important than scholastic goals, including matriculation degree.

"Education is important. If you help [the student] feel good in school it is more important than any subject you will teach" (I, 55) "...To give them a chance. To make them believe in themselves. To let them know they can finish high school... In the long run it is the finals... students with less failing marks..." (Y, 50) "My goal is to help them pass these four years in the best way socially, scholastically and emotionally... " $(D, 45)$ "To be good people... It is more important to me than success or a career... I want all of them to have full matriculation degree, with the best marks possible... It enables them to realize they can do great things. That they are amazing people..." $(D, 48)$

Subject teachers expressed scholastic goals as well as educational goals. Their scholastic goals were related mainly to their relevant subject.

"When they see you as a person... they can study... you can make them study... to bring the students to success out of love for the subject... We prepare them for the finals, but the learning process is more important..." $(H, 27)$ "It is important for me that [the student] will succeed in my subject. I am responsible for my subject..." $(M, 48)$ "To teach them linguistic skills... to pass the finals... Inside the classroom I want a good learning atmosphere...Cooperation between teacher and students. Cooperation among students in learning the language..." $(L, 56)$

2. "Teaching them is only supplementary to me..."

Interviewed teachers described their daily routine as comprised of many practices and chores. Homeroom educators emphasized practices that are related to educational aspects such as inclusion, acceptance and guidance.

"Teaching them is only supplementary to me... a subject teacher, eventually concentrates on teaching... his goal eventually is pedagogic." $(D, 48)$ "I can create changes for the students... I am a source of warmth and love as well as setting boundaries. I consider it a part of my role... a subject teacher is more directed to 
matriculation and learning. He has the curriculum that obliges him. They are adolescent. I want them to learn responsibility..." $(M, 38)$

Subject teachers, while stating educational practices such as inclusion, acceptance and guidance, emphasized practices that are related to scholastic and instructional aspects, such as students' learning processes and achievements attainment.

"I am responsible for teaching my subject materials. They are responsible for nurturing the spirit and the person as a whole... I like to invest everything in teaching." (L, 56) "I need to prepare my lessons...not to come unprepared. The intermission in between is dedicated to conversations with students, passing questions...to maximize the students' abilities in the subject." $(H, 33)$ "My role is to teach my subject as well as educating. Our main goal is to complete the teaching program. To prepare them to the finals..." $(Y, 64)$

As interview analysis shows, there are clear dissimilarities among homeroom educators and subject teachers related to different themes. The question arises as to what are the implication and insights that can be drawn from this analysis in order to improve our understanding of the different roles' perceptions, as well as their possible contribution to the promotion of general educational objectives.

\section{Discussion}

International comparison performed by tests such as PIZA and TIMSS provides important data for countries ranking in academic achievements, as well as for analyzing school factors of quality and equality ${ }^{44}$. In the reports produced by the OECD, there were suggestions of several changes school systems as a whole should undertake in order to promote inclusive education alongside academic achievements. These changes relate to schools' objective definition process and evaluation methods; application of prevention strategies at the early stages of schooling; 45 teachers - students relationship ${ }^{46}$ and the important role of the homeroom educator i.e. a teacher who by

${ }^{44}$ OECD, PIZA 2000 School factors related to Quality and Equity - 2000, OECD, Equity and Quality in Education: Supporting Disadvantaged Students and Schools Executive Summary, 2012, OECD, PISA 2012 Results: Ready to Learn - Students' Engagement, Drive and Self-Beliefs (Volume III), 2013.

45 OECD, Strong Performers and Successful Reformers in Education: Lessons from PIZA for the United States, 2010, 10/1787/9789264096660-en

46 OECD, 2013, et al. 
his/her role definition establishes a closer and more personal relationships with the students, and thus leads them to higher academic achievements ${ }^{47}$.

Schools as education systems should provide their students with academic training and achievements as well as social, ethical and behavioral focused mentoring ${ }^{48}$. In the Israeli education system these two objectives can be seen as reflecting the dual teachers' role definitions operating side by side inside the schools - the role of the homeroom educator and the role of the subject teacher ${ }^{49}$.

Considering the student as a whole person, and responding to personal parameters and issues as well as academic behaviors and demands is essential in order to promote students' sense of belonging and success ${ }^{50}$. Homeroom educators stated the importance of considering all aspects of students' lives as influencing their learning processes. Subject teachers, on the other hand, concentrated on the academic aspects in their relationships with the students, claiming it is the homeroom educators' role to obtain and address additional information. An example of that can be seen in teacher - parent relationships. All the homeroom educators consider it vital to communicate with all of their students' parents. Most subject teachers didn't consider it to be crucial, and often used the homeroom educator as a mediator between themselves and the parents.

Researches have emphasized the importance of personal, almost parental, attitude in promoting academic achievements, as well as social, behavioral and ethical achievements ${ }^{51}$. All interviewees have emphasized the importance of ongoing close relationship between the teacher and the students as a tool to enhance learning and promote academic, social behavioral and ethical achievements. Different practices were employed in order to establish and sustain these relationships. However, homeroom educators were more invested in their relationships with their students. Some stated that the parental aspect is part of their role perception.

As can be expected, different role definitions reveal themselves in different role perceptions. The holistic perception of the homeroom educator role as expressed in its formal role definition ${ }^{52}$ comes to life in teachers expressions concerning their perception of their student, their student-teacher rela-

\footnotetext{
47 OECD, 2010, et al.

$48 \mathrm{~S}$. Sherman, et. al.

${ }^{49}$ Ministry of Education, et al.

50 J. Korczak et al.; S. Sherman, et al.

51 K.P. Wentzel, et al.

52 Ministry of Education, et al.
} 
tionships, and their emphasis on educational practices and goals. These expressions were more holistic in nature.

Subject teachers' formal role definition focuses on their subject scope, its curriculum, practices and achievements ${ }^{53}$. The subject teachers' statements articulated this subject-centered definition. These statements, although valuing educational objectives and practices, highlighted academic objectives and practices which are by nature subject centered.

Homeroom educators and subject teachers were well aware of their different role description and its implications as well as their counterpart role description and implications. These well-defined roles are indeed complementary by nature as research suggested ${ }^{54}$.

\section{Summary and conclusions}

High school years are the corridor leading to adult life. In order to succeed a student must acquire knowledge and education, skills, norms and values that will facilitate his / her successful participation in society. High school teachers hold a great responsibility in their hand. They are the mentors and the facilitators of society's next generation. Thus, the education system is perceived as an important supporter of socialization processes, whose obligation to its clients far surpass their learning needs and desires. It is aimed not only at the acquisition of knowledge but also to heal and repair social exclusion and inequalities, by giving answers to personal, behavioral and moral needs all embodied within the term "educational objectives".

The Ministry of Education is the governmental entity responsible for setting educational goals for the entire student population in Israel. In recent years, these objectives have always included a reference to the students' academic achievements, along with an expectation to reduce the achievement gaps found in the schools ${ }^{55}$ and promote inclusion in the educational system ${ }^{56}$. The teaching staff responsible for promoting these objectives combines two distinctive role - the homeroom educator and the subject teacher. Results from qualitative analysis show differences between these two roles in their perception of the students, student-teacher relationship and ex-

53 Ibidem.

$54 \mathrm{~S}$. Sherman, et. al.

${ }_{55}$ M. Beller, Assessment in the Service of Learning: Theory and Practice, Israel: Rama - The National Authority for Measurements and Evaluations in Education, 2013.

56 Ministry of Education, MATANA (Planning, administration, and preparation package for 2014/2015), Pedagogic Administration [Access: January 2015]. 
pressed practices and objectives. Most interviewees were in agreement concerning the defined features of each role. There was an agreement that homeroom educators tend more to the socialization aspects of teaching in comparison with subject teachers. The homeroom educator role was perceived as more demanding and intense. Some of the interviewed homeroom educators, stated that concentrating in that role come on the expense of a professional investment as a subject teacher. It is important to consider whether this apparent split advances the achievements of formal educational objectives.

The interviewed teachers in both roles emphasized the importance of an ongoing, supportive teacher-student relationship, but there was an agreement that homeroom educators invest more resources in order to obtain those. Homeroom educators based their relationships with the students on their holistic view of the students, as well as on their overall responsibility for them. Subject teachers invested in these relationships within the scope of their distinctive subject, and under the limitation of teaching approximately 100 students.

The role of the homeroom educator corresponds well with the OECD recommendation for "a homeroom teacher" as a tool to promote educational inclusion as well as academic achievements among diverse student population $^{57}$. As such, further research is needed in order to learn more about the special features of that role and their influence over issues such as educational inclusion, school climate, dropout rates and narrowing the achievements gap among various students.

Special attention should be given to the subject teachers' role. Its position in school, which can be perceived as subordinate to the homeroom educators' one, can affect its ties to school personnel and school objectives. Since subject teachers' ties to the students can be perceived as less profound and intense, it can affect their ability to manage the classroom and successfully confront disciplinary issues. Further research is necessary in order to learn more about the special features of the subject teachers' role.

As stated earlier, all teachers are expected to be educators. Yet, the supporting socializations process aspects fall mainly in the realm of homeroom educators' role. This gives rise to three questions: Since subject teachers are evaluated mainly on their students' academic achievements, should their main emphasis be academic practices? Second, are these role differences taken into the account when implementing educational processes? And finally, quantitative evaluation for academic achievements is well defined and

57 OECD 2010, et al. 
implied; should socialization/educational achievements be evaluated quantitatively as well?

Socializations and academic aspects are all part of the role definition of what can be perceived as the valuable role of all - the teacher's role. A combination of those aspects in the instruction practices can promote teachers' sense of success in fulfilling the educational system objectives, as well as promoting students' inclusion and achievements. Thus preliminary qualitative research which was conducted in one rural high school should pave the way for other researches to follow. Every child is a whole world, and we all need a teacher for life.

\section{BIBLIOGRAPHY}

Adan S., Henryk Goldszmit - Janusz Korczak - The Man, The Educator, The author, The Janusz Korczak Society in Israel, Jerusalem 2000. (Hebrew)

Adar T., An Introduction to Education and Teaching, Gomeh - Science and Research books, Zerikover Pub., Tel Aviv 1974. (Hebrew)

Aloni N., Preface: The Philosophy as the Love of Wisdom and the Yearning for Comprehensive Understanding in the Art of Life, [in:] Becoming Human, Philosophy of Education: An Anthology, Ed. N. Aloni, Mofet Institute, Hakibutz Hmeochad Pub., Tel Aviv 2005. (Hebrew)

Bakshi-Brosh I., The Significance of the Roles of Homeroom Educators and Subject Teachers in the Israeli Education System, Ben Gurion University of the Negev 2005. (Hebrew)

Beller, M. Assessment in the service of learning: Theory and Practice, Rama - The National Authority for Measurements and Evaluations in Education, Israel 2013. (Hebrew)

Bernahu G., Inclusive Education in Sweden: Responses, Challenges, and Prospects, International Journal of Special Education, 2011, 26, 2.

Blau I., Hmeiri M., Implementing Technological Change at school: The Impact of Online communication With families on Teachers interactions Through Learning Management System, Interdisciplinary Journal of E-Learning and Learning Objects IJELLO special series of Chais Conference 2010 best papers, 2010, 6 .

Bogdan R.C., Biklen S.K., Qualitative Research for Education - an Introduction to Theories and Methods, 5th edition, Pearson Education Inc., U.S.A. 2007.

Bowels S., Understanding education and the reproduction of the social division of labor, Power and Ideology in Education, Eds. J. Karabel, J. Halsey, A.H. Oxford University Press, New York 1977.

Council for Higher Education The Council Resolution Concerning 'Guidelines For Teachers Training Program in Academic Institutions in Israel - Ariav Committee Report, Israel 2006. (Hebrew)

David K., Kibutzim and Moahavim's Youth Favors the Army MyNet http://www.mynet. co.il/articles/0,7340,L-3999693,00.html [Access: August, 2015].

Gordon D., Ackerman W.I., The Mechanech: Role Function and Myth in Israeli secondary Schools, Comparative Education Review, 1984, 28, 1. 
IEA - International Association for the Evaluation of Educational Achievements TIMSS 2011 http://www.iea.nl/timss_2011.html [Access: August 2015].

Korczak J., The child religion, Bet Lochamey Hagetaot and Hakibutz Hameochad Pub. 1978. (Hebrew)

Lam T., Educational Ideologies and Teaching Methods, Development in Teaching: The Israeli Case, Eds. R. Glubman, Y. Iram, Ramot pub., Tel Aviv University 1999. (Hebrew)

Ministry of Education, MATANA (Planning, administration, and preparation package for 2014/2015), Pedagogic Administration. [Hebrew]. http://cms.education.gov.il/ EducationCMS/Units/MinhalPedagogi/matana/2015.htm [Access: January 2015].

Ministry of Education, Teaching staff work regulations. http://cms.education.gov.il/ EducationCMS/UNITS/Sherut/Takanon [Access: January 2015]. (Hebrew)

Oakeshott M., Learning and Teaching, The Concept of Education, Ed. R.S. Peters, Routledge and Kegan Paul, London 1966.

OECD, PISA 2012 Results: Ready to Learn - Students' Engagement, Drive and Self-Beliefs, OECD Publishing, 2013.

OECD, Equity and Quality in Education: Supporting Disadvantaged Students and Schools Executive Summary, 2012 www.oecd.org/edu/equity [Access: 2013].

OECD, Strong Performers and Successful Reformers in Education: Lessons from PIZA for the United States, 2010, http://dx.doi.org 10/1787/9789264096660-en [Access: 2013].

OECD, PIZA 2000 School factors related to Quality and Equity - PIZA 2000 pub., Available: http:/ / www.oecd.org/dataoecd/15/20/34668095.pdf [Access: January 2015].

Peters R.S. What is an Educational Process? [in:] The Concept of Education, Ed. R.S. Peters, Routledge and Kegan Paul, London 1966.

Razer M., Mittelberg D., Motola M., Bar Gosen N., Inclusion and Achievement in Education: Contradictory or Complementary Goals?, Dvarim Oranim College 2013, 6. (Hebrew)

Razer M., Mittelberg D., Motola M., Bar Gosen N., Israeli high school teachers' perceptions and attitudes towards a pedagogy of inclusion, International Journal of Inclusive Education, 2015. DOI: 10.1080/13603116.2015.1019373

Sela A. 2011, 'Text-Books and Text people' What is the Role of the Mechanech in the Jewish Secular High School in Israel, and What is the place of the Jewish Texts Within That Role? Doctoral dissertation, William Davidson Graduate School of Jewish Education, NY 2011.

Sherman S., Responsiveness in Teaching: Responsibility in Its Most Particular sense, The Educational Forum, 2004, 68.

Tadmor Y., Homeroom Teachers as Key Figures in Education, Words That Teach: Collected Lectures and Articles, Ed. Y. Tadmor, Kedem Pub., Tel Aviv 1999. (Hebrew)

Walla! News. Where do most moral and ethical high school students in Israel study? http://news.walla.co.il/item/2880263 [Entry: 11.8.2015].

Wentzel K.P., Are Affective Teachers Are Like Good Parents? Teaching Styles and Student Achievements in Early Adolescence, Child Development, 2002, 73, 1.

Yin R.K., Qualitative Research from Start to Finish, Guilford Press, NY 2011.

Zidkiyaho S., Elam N., Fisherman S., Ronen H., Classroom Management, Mofet institute 2008. (Hebrew) 